\title{
Competences development and turnover intentions: the serial mediation effect of perceived internal employability and affective commitment
}

\author{
Ana Moreira
}

Department of Social and Organizational Psychology, ISPA - Instituto Universitário, Lisboa, Portugal

Francisco Cesário

Department of Social and Organizational Psychology, ISPA - Instituto Universitário, Lisboa, Portugal and Universidade Europeia, Lisboa, Portugal

Maria José Chambel

CICPSI, Faculty of Psychology, Universidade de Lisboa, Lisbon, Portugal, and

Filipa Castanheira

Nova School of Business and Economics, Universidade Nova de Lisboa, Lisbon, Portugal

\begin{abstract}
Purpose - This study aims to explore the serial mediation effect of perceived internal employability and affective commitment in the relationship between the organisational practices of competences development and turnover intentions.

Design/methodology/approach - The methodology was quantitative and is based on a survey with a sample of 313 participants, all of whom were employed in several organisations located in Portugal.

Findings - A significant and negative effect of organisational practices of competences development, perceived internal employability and affective commitment on turnover intentions was verified. A total serial mediation effect was also found from perceived internal employability and affective commitment in the relationship between organisational practices of competences development (i.e., training, individualised support and functional rotation) and turnover intentions.

Practical implications - These practices should be developed by leaders of organisations in order that employees feel that the organisation is investing in their development, which can lead to an increase in their emotional attachment towards the organisation and consequently increase their desire to stay in the organisation.

Originality/value - This study makes two important contributions. First, it confirms the existence of a significant and negative relationship between perceived internal employability and turnover intentions. Second, it
\end{abstract}

(C) Ana Moreira, Francisco Cesário, Maria José Chambel and Filipa Castanheira. Published in European Journal of Management Studies. Published by Emerald Publishing Limited. This article is published under the Creative Commons Attribution (CC BY 4.0) licence. Anyone may reproduce, distribute, translate and create derivative works of this article (for both commercial and noncommercial purposes), subject to full attribution to the original publication and authors. The full terms of this licence maybe seen at http://creativecommons.org/licences/by/4.0/legalcode
Competences development and turnover intentions

Received 19 May 2019 Revised 11 December 2019 8 February 2020 Accepted 1 June 2020 
EJMS

25,1 proves the existence of a total serial mediation effect of perceived internal employability and affective commitment in the relationship between organisational practices of competences development and turnover intentions.

Keywords Organisational practices of competences development, Internal employability, Affective commitment, Turnover intentions

Paper type Research paper

\section{Introduction}

Currently, the organisational context is witnessing a high rate of employee turnover, which has become a significant problem for organisations and consequently for human resources management, leading to the loss of experienced employees, which, in turn, entails high replacement costs (Akunda, Chen, \& Gikiri, 2018; Reich, 2008). In this context, organisations need to form and maintain long-term relationships which are relevant to retaining these employees, because employees are considered to be the most valued internal resources of competitive advantage. (Rahman, \& Nas, 2013; Wright, Dunford, \& Snell, 2001). Retaining these employees will increase organisations' competitive edge in an ever-changing labour market, which, according to the "Resource-based view", could add value and make it difficult for others to imitate their human capital (Afiouni, 2007; Barney, 1991). When an organisation is able to determine its strategic resources, it can become more competitive and subsequently achieve a sustainable advantage which helps it succeed. Several authors have suggested that the best way to achieve employee retention is to make employees feel that the organisation cares about them (Dawley, Houghton, \& Bucklew, 2010; Maertz, Griffeth, Campbell, \& Allen, 2007) and invest in the development of their competences (Jimenez \& Valle, 2013). When this occurs, employees feel that should their position be terminated, they would nonetheless be able to occupy another position within the organisation - in other words, their perceived internal employability is high (Cesário, Gestoso, \& Peregrin, 2012). Under these conditions, the employee feels emotionally connected to the organisation, that is to say, they remain affectively committed to it (Meyer \& Smith, 2000), which thus reduces their turnover intentions (Meyer, Allen, \& Smith, 1993; Meyer, 2014).

This study aims to analyse whether perceived internal employability and affective commitment can explain the relationship between organisational practices of competences development and turnover intentions. Previous studies, such as that of Benson (2006), have analysed the mediating effect of affective commitment between organisational practices of competence development and turnover intentions. Other authors, such as Nelissen, Forrier and Verbruggen (2016), have studied the mediating effect of affective commitment on the relationship between the perception of internal employability and turnover intentions.

This study innovates by developing an integrated approach which includes two mediating mechanisms which are characterised by a precedent-consequent relationship. The goal of this study is to provide organisations with further details about the importance of organisational practices of competences development to retain the best employees.

To test the serial mediating effect of internal employability and affective commitment on the relationship between organisational practices of competence development and turnover intentions, we used the correlational quantitative method. The results verified that employees valued support for their development of competences, which strengthened their connection with the organisation.

\section{Literature review}

Organisational practices of competences development and turnover intentions

Investment in the development of employees is considered to be a fundamental principle for maintaining and developing competences of both employees and the organisation as a 
whole (Lee \& Bruvold, 2003). According to the Human Capital Theory (Schultz, 1961), when an organisation is successful in the implementation of practices that promote employee competences, this creates a means (human capital) which distinguishes that organisation from others and increases its competitiveness.

Competences development practices are those activities which are promoted by organisations that are perceived by employees to be valuable and which contribute to their professional development (Campion, Cheraskin, \& Stevens, 1994; Jimenez \& Valle, 2013; Krishnapriya \& Baral, 2014; Schneider, Brief, \& Guzzo, 1996). Numerous methodologies focus on competences development. De Vos, De Hauw and Van der Heijden (2011) proposed a model where they identified three different methods that organisations could adopt for that purpose, namely, training, functional rotation and individualised support. In this model, training includes formal and informal training, which is also known as on-thejob training. Formal training can be delivered in a classroom or through participation in workshops/conferences, where new competences are developed from interacting with fellow participants. As for on-the-job training, employees enjoy several ways of learning, especially with the support of more experienced colleagues who can guide them through their work. This also represents an opportunity for employees to experience other functions inside the organisation - which is called functional rotation. Individualised support was also studied, that is to say, the type of support and advice that employees obtain from someone within the organisation regarding their professional development. Individualised support includes coaching programmes which aim to develop employee competences regarding objectives, not only by improving their performance, but also their quality of life within the organisation (Brock, 2006). Another component of individualised support is the assignment of a senior member by the organisation to support employees in case any question arises regarding their career (mentoring), as well as the possibility of being comfortable enough to speak about their career development with their manager.

Benson (2006) studied the consequences of introducing competences development programmes for employees and concluded that reducing turnover intentions is the main consequence of the implementation of these programmes. Turnover intentions are understood to be the employees' desire to leave the organisation and search for another job (Benson, 2006; Kim, 2014; Yang, Wan, \& Fu, 2012). Following this line of research, Lee and Bruvold (2003) suggest that the reasons for this reduction can range from the processes of social comparison through to compensation for the support given by the organisation and its investment in the competences development of their employees. With regards social comparison, Adams (1965) shows that employees often engage in social comparison processes and compare their organisation with others and concludes that if their organisation offers them more opportunities for competences development, then they will consider the value of their organisation to be greater.

Shore, Tetrick, Lynch, and Barksdale (2006) suggest that higher levels of organisational investments are associated with social exchange relationships which generate feelings of duty from the employee. Bearing in mind the premise of social exchange developed by Blau (1964), and also the norm of reciprocity developed by Gouldner (1960), these feelings of duty influence employees to benefit the organisation by performing behaviours which exceed the minimum requisites that their job demands. One of the ways an organisation can secure its investment in employees is by diminishing their turnover intentions (Kalleberg \& Rognes, 2000).

The relationship between competences development programmes and turnover intentions is sustained by several studies - whose conclusions point towards a negative association between these two constructs (Schmidt, Willness, Jones, \& Bourdage, 2016; Slavich, Cappetta, \& Giangreco, 2014). The study of Tanure, Evans and Pucik (2007) is 
EJMS

25,1

\section{Perceived employability and turnover intentions}

In addition to competences development programmes, it is also important to take into account the policies of flexibility and competitiveness which are implemented in the workplace, where the perception of employability can be considered to be a strategy to enhance employee development (Sánchez-Manjavacas, Saorín-Iborra, \& Willoughby, 2014).

The perception of employability emerges as a consensual factor with regards the ability of individuals to experience transitions in the workplace, where this capability is a direct consequence of their competences, their knowledge and their adaptability (De Cuyper, Bernhard-Oettel, Berntson, De Witte, \& Alarco, 2008). For De Witte (2005), the perception of employability is divided between perceived external employability and perceived internal employability. Perceived external employability refers to the perception that the employee must get a new job in another organisation, should their current one be eliminated (De Witte, 2005). Perceived internal employability refers to the perception that an employee possesses of their capability to perform another function within the organisation in the event that their current job is eliminated (De Witte, 2005).

Acikgoz, Sumer and Sumer (2016) show that the relationship between perceived internal employability and turnover intentions can be interpreted by using the Conservation of Resources theory. This theory proposes that employees seek to create, protect and maintain their resources because achieving positive results depends on the possession of these resources (Hobfoll, 1989; Pinto \& Chambel, 2008). Given that perceived internal employability can be considered to be a resource (De Cuyper, Mäkikangas, Kinnunen, Mauno, \& Witte, 2012), it is only logical that if employees perceive their high internal employability, then they will not want to lose such resources, and consequently, their turnover intentions decrease. Nevertheless, no studies were found in which the relationship between perceived internal employability and turnover intentions is significant. Examples include studies carried out by SánchezManjavacas et al. (2014) and Usmani (2016). De Cuyper, Mauno, Kinnunen, \& Mäkikangas (2011) also found no significant relationship between these variables, and suggested the existence of moderators or mediators in this relationship.

Although a significant relationship was not identified in previous studies between perceived internal employability and turnover intentions, based on the Conservation of Resources theory, we decided to continue to study this relationship and examined whether these two variables were significantly associated. Accordingly, using this theory, we decided to study the perception of internal employability exclusively. Accordingly, we have considered that perceived internal employability is the mechanism which diminishes turnover intentions. Thus, we propose $\mathrm{H} 2$ : 
H2. Perceived internal employability has a significant and negative effect on turnover intentions.

\section{Affective commitment and turnover intentions}

Affective commitment can be characterised as the emotional connection between the employee and the organisation and it can be defined as the identification and emotional commitment of the employee towards the organisation, leading to them remaining there (Cho \& Huang, 2012; Meyer, 2014). Affective commitment is developed through previous work experiences in the organisation which usually satisfy employees' psychological needs (e.g. the development of competences), and thus makes them feel comfortable within the organisation and competent when performing their job (Meyer \& Allen, 1991; Meyer, Allen, \& Topolnytsky, 1998; Ng, 2015). When affective commitment is high, employees become excited about their work and contribute to their organisation's success (Allen \& Meyer, 1996; Meyer \& Herscovitch, 2001; Meyer, Becker, \& Van den Berghe, 2004). Several authors believe that the main interest in studying affective commitment is its impact on turnover intentions, given that affectively committed employees wish to remain in the organisation (Meyer, 2014; Mowday, Porter, \& Steers, 1982). In the three-component model of Meyer and Allen (1991), affective commitment is a precedent for turnover intentions.

A study conducted by Wasti (2003) verified that, although the three components of organisational commitment have a negative effect on turnover intentions, affective commitment is the component with the strongest effect. This conclusion leads to H3:

H3. Affective commitment has a significant and negative effect on turnover intentions.

\section{Serial mediation effect of perceived internal employability and affective commitment}

According to Becker (1965), general competences increase productivity in any organisation, whereas specific competences increase productivity in a given organisation. The Human Capital theory developed by Schultz (1961) suggests that the promotion of general competences development increases perceived external employability, whereas the promotion of specific competences development increases perceived internal employability (Becker, 1965; Lynch \& Cross, 1991; Mincer \& Higuchi, 1988). Human resource managers should concern themselves with controlling their employees' perceived internal employability, given that the most valuable employees can be attracted by job offers from the external market (Roehling, Cavanaugh, Moynihan, \& Boswell, 2000). Organisations must, therefore, promote specific competences development programmes to retain these employees. Baruch (2001) believes that if an organisation shows a concern about employees' competences development and implements practices which will enhance them, this can be considered to be the essence of perceived employability, especially internal employability. Implemented changes can be internal, examples being a promotion, relocation or task enrichment (Ostroff \& Clark, 2001).

For employees, the fact that organisations implement competences development practices can also be seen to be a concern about their development, which leads them to reciprocate and increases their affective commitment (Wayne, Shore, \& Liden, 1997). Hence, an exchange with benefits to both parties is established (Eisenberger, Huntington, Hutchison, \& Sowa, 1986), which can be interpreted by taking into consideration the social exchange premise (Blau, 1964) and also the reciprocity norm (Gouldner, 1960), which thus supports that perceived internal employability is positively associated with affective commitment (De Cuyper \& De Witte, 2011). When employees perceive that they have the 
EJMS

25,1

10

opportunity to perform another function within the organisation in the event that their current job is eliminated, they feel more connected to the organisation and develop greater affective commitment (De Cuyper et al., 2008).

In conclusion, the implementation of a competences development programme can install better internal perceived employability in employees (De Cuyper et al., 2008). Enhancing employees' perceived internal employability makes them feel more affectively committed with the organisation (De Cuyper \& De Witte, 2011) and decreases their turnover intentions and results in greater organisational loyalty (Benson, 2006). Perceived internal employability and affective commitment are the mechanisms that explain the association between organisational practices of competences development and turnover intentions. As a result of this conceptualisation, our objective is to analyse the relationship between organisational practices of competences development and turnover intentions through perceived internal employability and affective commitment, which leans to the formulation of the following hypothesis:

H4. Perceived internal employability and affective commitment both represent an indirect effect in series in the relationship between organisational practices of competences development [(a) training, (b) individualised support and (c) functional rotation] and turnover intentions.

To integrate the various hypotheses formulated, a theoretical model was developed (Figure 1), which aims to synthesise the expected relations and associations between the constructs.

\section{Method}

\section{Procedure}

For data collection, we had the support of the "Pessoas 2020" organisation, whose associates distributed a questionnaire composed of the scales to measure each studied variable. The sampling process was non-probabilistic and convenience-based (Trochim, 2000). The questionnaire was created and posted online, using the Google Docs platform.

Respondents included 313 subjects, all of whom had worked during the past six months as employees in organisations located in Portuguese territory, because the objective of the study was to test Portuguese employees' behaviour and to determine how to reduce their intentions to leave their organisations. The data were obtained in September and October 2017, when Portugal was recovering from a deep economic crisis in which the unemployment rate was approximately $9 \%$.

The online published questionnaire contained information relative to the study's objective and guaranteed answer confidentiality. It included five questions designed to characterise the sample (age, sex, academic qualifications, seniority in the organisation and type of employment contract) and four scales (organisational practices of competences development, affective commitment, internal employability and turnover intentions).

Figure 1.

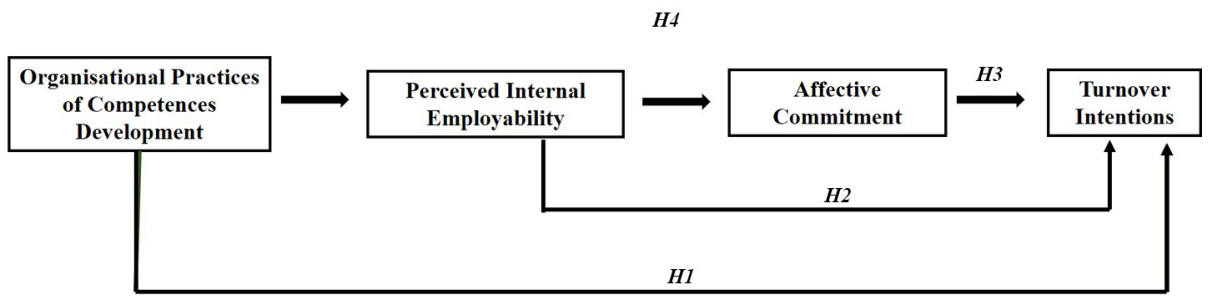




\section{Participants}

Among the participants of this study, $72.5 \%$ were female, with a mean age of 41.02 years $(\mathrm{SD}=11.94)$, ranging from 19 to 65 years. Their literary qualifications were education up to the 12 th year (14.4\%); bachelor's degree (49.8\%) and master's degree or higher $(35.8 \%)$. The types of employment contract considered were as follows: temporary contract $(14.1 \%)$; fixed-term contract $(26.5 \%)$ and permanent contract $(56.4 \%)$. The average seniority of the sample in the organisation was 10.75 years $(\mathrm{SD}=10.95)$.

\section{Data analysis procedure}

The first step in the analysis was to test the metric qualities of the four instruments used in this study. To test the validity of those instruments that measure organisational practices of competences development, perceived internal employability and affective commitment, we used confirmatory factor analysis, using the AMOS 24 software for Windows. The procedure used was based on the "model generation" logic (Jöreskog \& Sörbom, 1993), by considering the analysis of its adjustment; interactively; the results obtained for the Chi-square $\left(\chi^{2}\right)<5$, the Tucker-Lewis index (TLI) $>0.90$, the goodness-of-fit index (GFI) $>0.90$ and the comparative fit index $(\mathrm{CFI})>0.90$; and the root mean square error approximation (RMSEA) $<0.08$. The turnover intentions instrument validity was tested with exploratory factor analysis, using SPSS Statistics 24 software, given that this instrument comprises only three items. Next, we tested the internal consistency of each instrument by calculating the Cronbach's alpha, whose value should range between "0" and "1", never assuming negative values (Hill \& Hill, 2002). These values were greater than 0.70 , which is the minimum value acceptable in organisational studies (Bryman \& Cramer, 2003). The construct reliability of the instruments of organisational practices of competence development and perception of internal and affective commitment was also tested, resulting in a value of 0.70 , which is considered to be the lowest acceptable value in organisational studies. The construct reliability for the turnover intentions instrument was not tested, because it comprised only three items. The normality of each item and instrument was tested by calculating the measures of central tendency as the median, asymmetry and kurtosis, as well as the minimum and maximum.

To test the mediation model, we used the PROCESS 2.16 macro developed by Hayes (2013), as this enabled us to test a mediation model with multiple mediators which operate in series. This process was chosen because it is advantageous for studying the serial effect of several moderators, as in the study of Carvalho \& Chambel (2015). To derive the direct and indirect effects, we first estimated path coefficients in the model of training with perceived internal employability and affective commitment as mediators (Model 1), followed by those from the model of individualised support (Model 2) and, finally, by those from the model of functional rotation (Model 3), as this macro enabled us to include only one predictive variable at a time.

\section{Measures used}

The socio-demographic questionnaire comprised five questions (sex, age, academic qualifications, seniority in the organisation and type of employment contract). The perception of organisational practices of competences development was measured using an instrument developed by De Vos et al. (2011), which had been adapted to the Portuguese language, comprising 12 items classified by a five-point Likert rating scale (ranging from 1 "Never" to 5 "Always"). To test its validity, we carried out a confirmatory factor analysis, which confirmed the existence of three factors, namely, training (Items 1, 2, 3, 4, 5 and 8), individualised support (Items 7, 11 and 12) and functional rotation (Items 9 and 10). It should be noted that it was necessary to withdraw Item 6 , as it presented a low factorial weight. We obtained adequate fit indices $\left(\chi^{2} / \mathrm{df}=2.57 ; \mathrm{GFI}=0.95 ; \mathrm{CFI}=0.94 ; \mathrm{TLI}=0.91 ; \mathrm{RMSEA}=0.071\right)$. In terms of internal
Competences development and turnover intentions 
EJMS

25,1

consistency, the Cronbach's alpha values presented are as follows: 0.81 for training; 0.67 for individualised support and 0.72 for functional rotation. The construct reliability for each dimension was 0.85 for training, 0.66 for individualised support and 0.74 for functional rotation. Regarding the internal consistency and construct reliability of the dimensions that compose this instrument, only individualised support presents values of slightly below 0.70 , which is the acceptable minimum in organisational studies (Hill \& Hill, 2002; Marôco, 2014). For training, the obtained values are good, and for functional rotation, they are reasonable. Neither the items nor the factors violate the normality distribution.

Perceived internal employability was measured using the eight items that make up the two dimensions of perceived internal employability, using an instrument developed by De Cuyper and De Witte (2010) classified by a five-point Likert rating scale (ranging from 1 "Completely disagree" to 5 "Completely agree"). The two dimensions comprising perceived internal employability are as follows: perceived internal qualitative employability (Items 2, 4, 5 and 8) and perceived internal quantitative employability (Items 1, 3, 6 and 7). For the authors of this instrument, the perception of internal employability is the perception of employees of occupying a better position than the current one within the organisation, should their function be eliminated. The perception of quantitative internal employability is the perception of employees of occupying a similar position within the organisation, should their function be eliminated. Given that internal employability's factorial structure was known, we performed a two-factor confirmatory factor analysis; however, not all adjustment indices obtained were adequate $\left(\chi^{2} / \mathrm{df}\right.$ $=5.15 ; \mathrm{GFI}=0.93 ; \mathrm{CFI}=0.95 ; \mathrm{TLI}=0.93 ; \mathrm{RMSEA}=0.112)$. Because the correlation between the two factors was " 1 ", it was decided to perform a new one-factor confirmatory analysis. This time, the obtained fit indices were considered adequate $\left(\chi^{2} / \mathrm{df}=2.73 ; \mathrm{GFI}=0.97\right.$; $\mathrm{CFI}=0.97$; TLI $=0.97$; RMSEA $=0.075$ ). Given these results, in this study, this instrument will be considered as one-dimensional. Internal consistency resulted in a Cronbach's alpha value of 0.91 and the construct reliability obtained was also 0.91 . Neither the scale nor the items violate the normality distribution. Both the internal consistency and construct reliability of this instrument are considered very good, with values above 0.90 (Hill \& Hill, 2002; Marôco, 2014).

Affective commitment was measured using the six items comprising the affective commitment subscale of the instrument developed by Meyer and Allen (1997) using a sevenpoint Likert-type rating scale (ranging from 1 "Completely disagree" to 7 "Completely agree"). We performed a one-factorial confirmatory analysis, obtaining adequate fit indices $\left(\chi^{2} / \mathrm{df}=2.16 ; \mathrm{GFI}=0.98 ; \mathrm{CFI}=0.99 ; \mathrm{TLI}=0.98 ; \mathrm{RMSEA}=0.061\right)$. In terms of internal consistency, we obtained a Cronbach's alpha of 0.89 and a construct reliability of 0.89 , which are considered good (Hill \& Hill, 2002; Marôco, 2014). Neither the scale, nor the items violate the normality distribution.

As for turnover intentions, this variable was measured using the three items that form the instrument developed by Bozeman \& Perrewé (2002), using a 5-point Likert-type rating scale (ranging from 1 "Completely disagree" to 5 "Completely agree"). Having performed an exploratory factor analysis, we obtained a Kaiser Meyer Olkin of 0.79 and an explained variance of $85.67 \%$. For internal consistency, we obtained a Cronbach's alpha of 0.92 , which is considered a very good value because it is above 0.90 (Hill \& Hill, 2002). Neither the scale nor the items violate the normality distribution.

\section{Results}

Two competing models were tested to examine whether all the constructs are represented by a one-factor model or by a six-factor model (training, individualised support, functional rotation, perceived internal employability, affective commitment and turnover intentions). Fit indices of the one-factor model were not adequate $\left(\chi^{2} / \mathrm{df}=5.43\right.$; GFI $=0.61$; $\mathrm{CFI}=0.69$; 
TLI $=0.66$; RMSEA $=0.119 ;$ SMRM $=0.19$ ). On the other hand, fit indices for the six-factor model were considered adequate, or very close to adequate values $\left(\chi^{2} / \mathrm{df}=2.05 ; \mathrm{GFI}=0.86\right.$; $\mathrm{CFI}=0.93$; TLI $=0.92 ;$ RMSEA $=0.058$; SMRM $=0.10$ ). Therefore, we conclude that the theoretical concept, which suggested six variables, adequately represents the observed data. Correlations are consistent with the theorised relationship pattern. The complete results are available upon request.

Upon analysing Figure 2, it is possible to verify that the training $(\beta=-0.33 ; \mathrm{p}<0.01)$, individualised support $(\beta=-0.34 ; p<0.01)$ and functional rotation $(\beta=-0.24 ; p<0.01)$ perceptions have a significant and negative effect on turnover intentions, given that the former variables are responsible for $16 \%$ of its variability, which confirms $H 1$. Perceived internal employability $(\beta=-0.60 ; p<0.01)$ possesses a significant and negative effect on turnover intentions, being responsible for $36 \%$ of its variability, which confirms $H 2$. Affective commitment $(\beta=-0.75 ; p<0.01)$ has a significant and negative effect on turnover intentions, being responsible for $57 \%$ of its variability, which confirms $H 3$.

The mediation hypothesis in this study stated that perceived internal employability and affective commitment represent an indirect effect in series on the relationship between organisational practices of competences development and turnover intentions. Models 1, 2 and 3 summarise the results of $H 4 a$ (Table 1 and Figure 3), H4b (Table 2 and Figure 4) and $H 4 c$ (Table 3 and Figure 5), respectively.

According to Table $1(H 4 a)$, we observed a significant total indirect effect, given that zero was not included in the confidence interval. The total indirect effect splits into three indirect effects, all of which are significant: the indirect effect in series; the indirect effect in which perceived employability mediates the relationship between training and turnover intentions; and the indirect effect in which affective commitment mediates the relationship between training and turnover intentions. By analysing the contrasts, we verified that the strongest indirect effect is the one which is exerted by affective commitment, which mediates the relationship between training and turnover intentions. When the mediators were introduced in the regression equation, the direct effect of training on turnover intentions was no longer significant, which leads us to affirm that we have a total mediation effect, which confirms our hypothesis (Figure 3).

According to Table $2(H 4 b)$, we observed a significant total indirect effect, given that zero was not included in the confidence interval. The total indirect effect splits into three

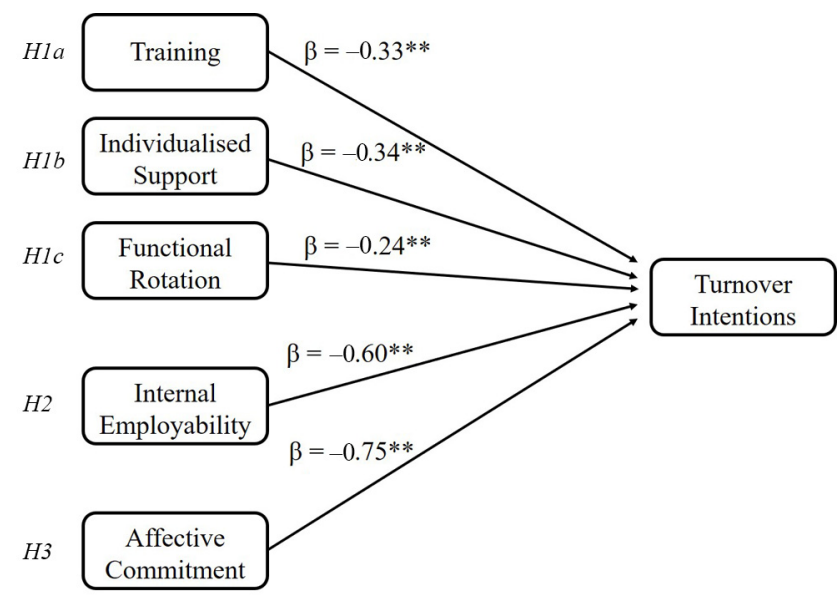

Competences development and turnover intentions 
EJMS

25,1

14

indirect effects, all of which are significant: the indirect effect in series; the indirect effect in which perceived employability mediates the relationship between individualised support and turnover intentions; and the indirect effect in which affective commitment mediates the relationship between individualised support and turnover intentions. By analysing the contrasts, we verified that the indirect effects do not differ significantly from each other. When the mediators were introduced in the regression equation, the direct effect of individualised support on turnover intentions was no longer significant, which leads us to conclude that we have a total mediation effect, confirming our hypothesis (Figure 4).

Table 1. Indirect effects of Model $1(H 4 a)$

\begin{tabular}{|c|c|c|}
\hline & Estimates & $\begin{array}{l}\text { ect effects } \\
\text { Confidence interval at } 95 \% \text { with } \\
\text { bootstrap correction }\end{array}$ \\
\hline \multicolumn{3}{|l|}{ Model 1} \\
\hline Total & $-0.46(0.07)$ & {$[-0.59 ;-0.33]$} \\
\hline Training $\rightarrow \mathrm{IE} \rightarrow \mathrm{TI}$ & $-0.09(0.03)$ & {$[-0.15 ;-0.04]$} \\
\hline Training $\rightarrow \mathrm{IE} \rightarrow \mathrm{AC} \rightarrow \mathrm{TI}$ & $-0.10(0.03)$ & {$[-0.16 ;-0.06]$} \\
\hline Training $\rightarrow \mathrm{AC} \rightarrow \mathrm{TI}$ & $-0.27(0.05)$ & {$[-0.37 ;-0.17]$} \\
\hline
\end{tabular}

Notes: Total effect: Training $\rightarrow \mathrm{EI}=-0.49(0.08)$. The standard error is in brackets. $\mathrm{TI}=$ Turnover intentions; $\mathrm{AC}=$ Affective commitment; $\mathrm{IE}=$ Perceived internal employability
Figure 3.

Model $1(H 4 a)$

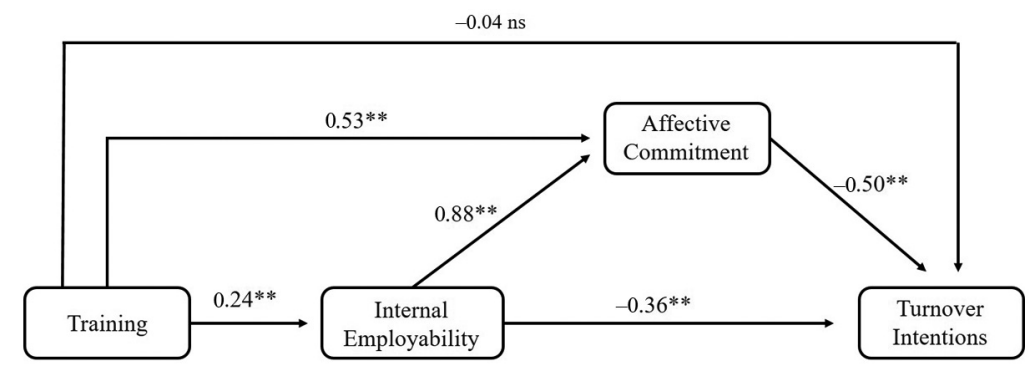

\begin{tabular}{lcc}
\hline & Estimates & $\begin{array}{c}\text { Indirect effects } \\
\text { Confidence interval at } 95 \% \text { with } \\
\text { bootstrap correction }\end{array}$ \\
\hline Model 2 & $-0.46(0.05)$ & {$[-0.56 ;-0.35]$} \\
Total & $-0.13(0.03)$ & {$[-0.20 ;-0.08]$} \\
IS $\rightarrow$ IE $\rightarrow$ TI & $-0.16(0.03)$ & {$[-0.22 ;-0.11]$} \\
IS $\rightarrow$ IE $\rightarrow$ AC $\rightarrow$ TI & $-0.16(0.04)$ & {$[-0.25 ;-0.09]$} \\
IS $\rightarrow$ AC $\rightarrow$ TI & Notes: Total effect: IS $\rightarrow$ EI $=-0.43$ (0.07). The standard error is in brackets. TI = Turnover intentions; \\
AC $=$ Affective commitment; IS $=$ Individualised support; IE $=$ Perceived internal employability
\end{tabular}

Table 2 .

Indirect effects of Model $2(H 4 b)$
Notes: Total effect: $\mathrm{IS} \rightarrow \mathrm{EI}=-0.43(0.07)$. The standard error is in brackets. TI $=$ Turnover intentions; $\mathrm{AC}=$ Affective commitment; IS = Individualised support; IE = Perceived internal employability 
According to Table $3(H 4 c)$, we observed a significant total indirect effect, given that zero was not included in the confidence interval. The total indirect effect splits into three significant indirect effects: the indirect effect in series; the indirect effect in which perceived internal employability mediates the relationship between the functional rotation and turnover intentions; and the indirect effect in which affective commitment mediates the relationship between the functional rotation and turnover intentions. Contrast analysis revealed that there were no significant differences between indirect effects. When the mediators were introduced in the regression equation, the direct effect of functional rotation development and turnover intentions on turnover intentions was no longer significant, which leads us to conclude that we have a total mediation effect, confirming our hypothesis (Figure 5).

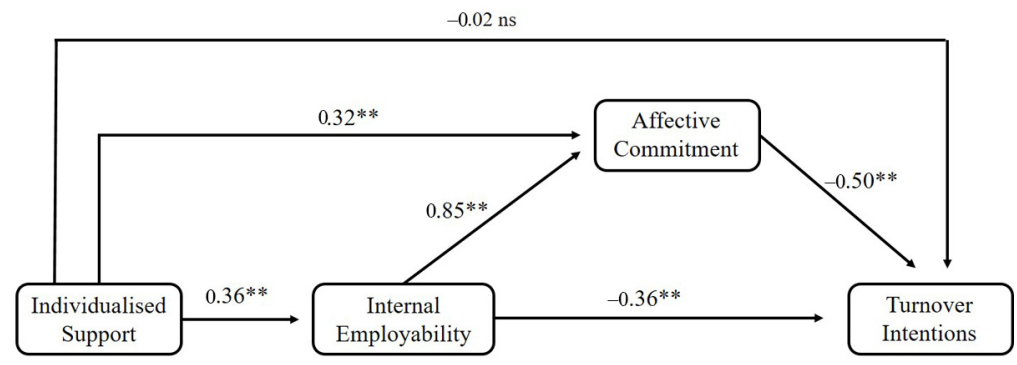

Figure 4. Model $2(H 4 b)$

Indirect effects

Confidence intervals at $95 \%$ with

Estimates bootstrap correction

\begin{tabular}{ll}
\hline Model 3 & \\
Total & $-0.37(0.05)$ \\
$\mathrm{JR} \rightarrow \mathrm{IE} \rightarrow \mathrm{TI}$ & $-0.12(0.03)$ \\
$\mathrm{JR} \rightarrow \mathrm{IE} \rightarrow \mathrm{AC} \rightarrow \mathrm{TI}$ & $-0.14(0.03)$ \\
$\mathrm{JR} \rightarrow \mathrm{AC} \rightarrow \mathrm{TI}$ & $-0.11(0.04)$
\end{tabular}

$$
\begin{aligned}
& {[-0.47 ;-0.27]} \\
& {[-0.18 ;-0.06]} \\
& {[-0.20 ;-0.09]} \\
& {[-0.19 ;-0.04]}
\end{aligned}
$$

Table 3.

Notes: Total effect: $\mathrm{JR} \rightarrow \mathrm{EI}=-0.28(0.06)$. The standard error is in brackets. $\mathrm{TI}=$ Turnover intentions; $\mathrm{AC}=$ Affective commitment; $\mathrm{JR}=$ Functional rotation; $\mathrm{IE}=$ Perceived internal employability

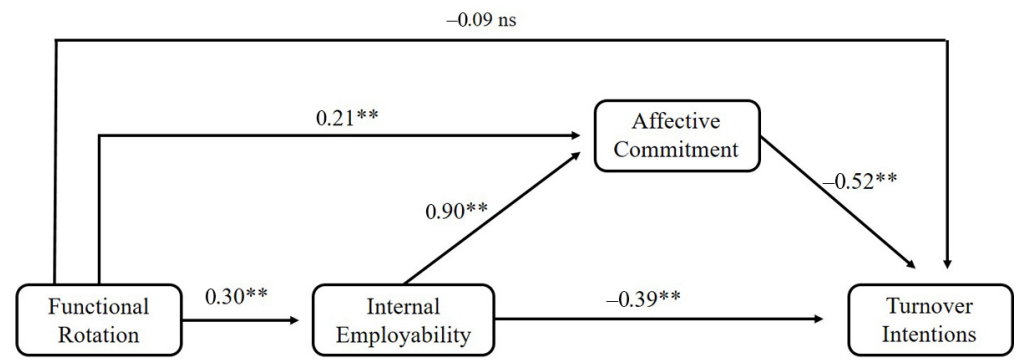

Figure 5. Model $3(H 4 c)$ 
EJMS

25,1

\section{Discussion and conclusions}

This study aimed to test the serial mediation effect of perceived internal employability and affective commitment on the relationship between organisational practices of competences development and turnover intentions. As expected, the results showed that organisational practices of competences development (training, individualised support and functional rotation), perceived internal employability and affective commitment all have a significant and negative effect on turnover intentions. As expected, perceived internal employability and affective commitment are mediators in series in the relationship between organisational practices of competences development and turnover intentions. Exceeding expectations was the finding that, in the presence of perceived internal employability and affective commitment as mediators in series, the relationship between organisational practices of competences development and turnover intentions was no longer significant. These results alone are enough to justify the importance of this study and its consequent impact on the literature.

As expected, the result for the first hypothesis showed the existence of a negative effect of organisational practices of competence development on turnover intentions. This relationship is in line with the finding of Kalleberg \& Rognes (2000), as when an organisation invests in its employees and promotes the development of its competences, one of the ways in which employees return this investment to the organisation is by diminishing their turnover intentions, with this relationship being interpreted as a social exchange (Blau, 1964) or a reciprocal response (Gouldner, 1960).

Our second hypothesis was corroborated, as we observed a significant and negative effect of perceived internal employability on turnover intentions. This result does not follow what is stated in the literature, as in previous studies, the relationship between perceived internal employability and turnover intentions was not revealed to be significant (De Cuyper et al., 2011; Sánchez-Manjavacas et al., 2014; Usmai, 2016). Based on the conservation of resources theory, this relationship can be interpreted as that employees who perceive high internal opportunities of development do not wish to lose that resource, which leads to decreased turnover intentions (Hobfoll, 1989; Pinto \& Chambel, 2008).

Third, as expected, we were also able to prove the existence of a significant and negative effect of affective commitment on turnover intentions. These results support those of the literature, especially the study of Meyer and Allen (1991), who consider that the main predictor of turnover intentions is organisational commitment - with its affective component revealing the strongest effect.

Finally, this study sought to understand the process that associates the organisational practices of competences development with turnover intentions. We proved the serial indirect effect of perceived internal employability and affective commitment on the relationship between organisational practices of competences development and turnover intentions. When an organisation promotes opportunities for the development of its employees, it adds value to its employees, and, in response, the employees demonstrate a larger connection to the organisation and a wish to remain there. This relationship can be interpreted in the light of reciprocity norms and social exchange theory. Among the three organisational practices of competence development, aligned with the perception of internal employability and affective commitment, those that demonstrate a stronger effect for the reduction of turnover intentions are training and individualised support. The dimension formation of the instrument used in this study contemplates not only formal training, but also on-the-job training (e.g. "A more experienced co-worker directed his own work, which was useful for his learning"), which, according to Markowitsch et al. (2001), encourages employees to take the initiative and cooperate, as well as learn and share knowledge. The 
dimension of individualised support encompasses the initiatives of career development (coaching and mentoring programmes) which are aimed at developing competences with specific targets of employees to improve not only their performance, but also their quality of life inside the organisation. These two practices refer to the personal contact which makes employees feel a strong affective connection to the organisation, in addition to a high internal employability perception, which encourages them to remain working for the organisation. Additionally, those items that compose the functional rotation only refer to the circulation between functions inside the organisation, rather than to personal relationships (e.g. "I had the chance of changing functions inside the company"), which therefore explains their smaller effect on turnover intentions.

\section{Limitations and suggestions}

This study has some limitations. The main limitation is that it is a transversal study, which did not allow us to establish any causal relationships between the variables. It would be preferable to carry out a longitudinal study to test causal relationships. Another limitation stems from using self-report questionnaires, which could have caused result bias. With the objective to diminish the impact of common method variance, we followed the methodological and statistical recommendations proposed by Podsakoff, MacKenzie, Lee and Podsakoff (2003).

Finally, we highlight as a limitation the fact that only internal perceived employability was studied, as we did not know what direction the relationship between perceived external employability and turnover intentions would take. It would be interesting to analyse this relationship, such as that occurred in the research of De Cuyper et al. (2011), where a positive relationship between perceived external employability and turnover intentions was hypothesised. However, as they did not find a significant relationship, they suggested the need for a study on the indirect effect of affective and calculative commitment on this relationship.

\section{Theoretical implications}

In this study, we proved the existence of a significant and negative relationship among organisational practices of competences development, perceived internal employability and affective commitment on turnover intentions. The relationship between affective commitment and turnover intentions confirms what has already been stated by several authors, among them being Meyer, Stanley, Herscovitch, and Topolnytsky (2002), who believe that organisational commitment is the variable which best predicts turnover intentions in the organisation, even in different contexts of organisational change. These authors also state that among the three components of organisational commitment, affective commitment is that which has the strongest relationship to turnover intentions. Consistent with the previous analysis, we found that the relationship between competences development practices and turnover intentions was also significant and negative. Kim (2005) emphasises that the development of competences is so crucial to organisations that they are obliged to invest in practices of competences development to decrease turnover intentions. With regards the significant and negative relationship between perceived internal employability and turnover intentions found in this study, this relationship is not consistent with that of previously published research, such as the studies of Sánchez-Manjavacas $e t$ al. (2014), Usmai (2016) and De Cuyper et al. (2011). However, these last authors suggest the existence of moderators or mediators in this relationship. Finally, we proved that perceived internal employability and affective commitment are the mechanisms which best help 
EJMS

25,1

18

explain the relationship between organisational practices of competences development and turnover intentions.

This study makes two important contributions to the literature. First, it confirms the existence of a significant and negative relationship between perceived internal employability and turnover intentions. Second, we proved the existence of a total serial mediation effect of perceived internal employability and affective commitment in the relationship between organisational practices of competences development and turnover intentions.

\section{Practical implications}

One of the strengths of this study is the fact that it indicates the existence of a serial mediation effect of perceived internal employability and affective commitment in the relationship between organisational practices of competences development and turnover intentions. The verification of this effect means that when the objective is to reduce turnover intentions, those responsible for human resources should promote competences development practices which specifically foster the perception of internal employability and affective commitment. These practices, together with other activities which can be developed within the organisation to ensure that employees are involved effectively, can reduce high levels of employee turnover, and thus diminish inherent high costs. These practices should also evidence the serial effect which underlies this relationship. The implementation of adequate, specific and innovative competences development practices (e.g. coaching, mentoring or functional rotation) enables employees to develop a better perception of internal employability (Baruch, 2001), which consequently enhances affective commitment (De Cuyper \& De Witte, 2011) and encourages them wish to remain with their current organisation (Benson, 2006).

\section{References}

Acikgoz, Y., Sumer, H. C., \& Sumer, N. (2016). Do employees leave just because they can? Examining the perceived employability - turnover intentions relationship. The Journal of Psychology, 150(5). Retrieved from: http://dx.doi.org/10.1080/00223980.2016.1160023

Adams, J. S. (1965). Inequity in social exchange. In Berkowitz, L. (Ed.), Advances in experimental social psychology, Vol. 2, pp. 267-299. New York, NY: Academic Press.

Afiouni, F. (2007). Human resource management and knowledge management: a road map toward improving organizational performance. Journal of American Academy of Business, 11, 124-130.

Akunda, D., Chen, Z., \& Gikiri, S. N. (2018). Role of HRM in talent retention with evidence. Journal of Management and Strategy, 9(2), 8, doi: 10.5430/jms.v9n2p8.

Allen, N. J., \& Meyer, J. P. (1996). Affective, continuance, and normative commitment to the organization: an examination of construct validity. Journal of Vocational Behavior, 49(3), 252-276.

Arthur, J. B. (1994). Effects of human resource systems on manufacturing performance and turnover. Academy of Management Journal, 37, 670-687.

Barney, J. B. (1991). Firm resources and sustained competitive advantage. Journal of Management, 17(1), 99-120.

Baruch, Y. (2001). Employability: a substitute for loyalty? Human Resource Development International, 4(4), 543-566. Retrieved from: http://dx.doi.org/10.1080/13678860010024518

Becker, G. S. (1965). A theory of the allocation of time. The Economic Journal, 75(299), 493-517.

Benson, G. S. (2006). Employee development, commitment and intention to turnover: a test of "employability" policies in action. Human Resource Management Journal, 16(2), 173-192. 
Blau, P. (1964). Exchange and power in social life, New York, NY: Wiley.

Bozeman, D., \& Perrewé, P. (2002). The effect of item content overlap on organizational commitment questionnaire-turnover cognitions relationships. Journal of Applied Psychology, 86(1), 161-173.

Brock, V. G. (2006). Who's who in coaching: Who shaped it, who's shaping it. In Bennet, J. L. \& Campone, F. (Eds), Proceedings of the fourth international coach federation coaching research symposium. (11-25). Lexington: International Coach Federation.

Bryman, A., \& Cramer, D. (2003). Análise de dados em ciências sociais. Introdução às técnicas utilizando o SPSS Para windows, 3rd ed., Oeiras: Celta.

Campion, M. A., Cheraskin, L., \& Stevens, M. J. (1994). Career-related antecedents and outcomes of job rotation. Academy of Management Journal, 37, 1518-1542.

Carvalho, V. S., \& Chambel, M. J. (2015). Perceived High-Performance work systems and subjective Well-Being. Journal of Career Development, 43(2), 116-129, doi: 10.1177/0894845315583113.

Cesário, F., Gestoso, C., \& Peregrin, F. (2012). Contrato de trabajo, compromiso y satisfacción: Moderación de la empleabilidad. RAE, 3, 345-359.

Cho, V., \& Huang, X. (2012). Professional commitment, organizational commitment, and the intention to leave for professional advancement. Information Technology \& People, 25(1), 31-54. Retrieved from: http://dx.doi.org/10.1108/09593841211204335

Dawley, D., Houghton, J. D., \& Bucklew, N. S. (2010). Perceived organizational support and turnover intention: the mediating effects of personal sacrifice and job fit. The Journal of Social Psychology, 150(3), 238-257.

De Cuyper, N., \& De Witte, H. (2010). Temporary employment and perceived employability: Mediation by impression management. Journal of Career Development, 37(3), 635-652.

De Cuyper, N., \& De Witte, H. (2011). The management paradox: self-rated employability and organizational commitment and performance. Personnel Review, 40(2), 152-172.

De Cuyper, N., Mauno, S., Kinnunen, U., \& Mäkikangas, A. (2011). The role of job resources in the relation between perceived employability and turnover intention: a prospective two-sample study. Journal of Vocational Behavior, 78(2), 253-263.

De Cuyper, N., Bernhard-Oettel, C., Berntson, E., De Witte, H., \& Alarco, B. (2008). Employability and employees' well-being: Mediation by job insecurity. Applied Psychology, 57(3), 488-509.

De Cuyper, N., Mäkikangas, A., Kinnunen, U., Mauno, S., \& Witte, H. D. (2012). Cross-lagged associations between perceived external employability, job insecurity, and exhaustion: Testing gain and loss spirals according to the conservation of resources theory. Journal of Organizational Behavior, 33(6), 770-788.

De Vos, A., De Hauw, S., \& Van der Heijden, B. I. J. M. (2011). Competency development and career success: the mediating role of employability. Journal of Vocational Behavior, 79(2), 438-447.

De Witte, H. (2005). Job insecurity: Review of the international literature on definitions, prevalence, antecedents and consequences. South African Journal of Industrial Psychology, 31(4), 1-4.

Eisenberger, R., Huntington, R., Hutchison, S., \& Sowa, D. (1986). Perceived organizational support. Journal of Applied Psychology, 71(3), 500-507.

Gouldner, A. W. (1960). The norm of reciprocity: a preliminary statement. American Sociological Review, 25(2), 161-178.

Hayes, A. F. (2013). An introduction to mediation, moderation, and conditional process analysis: a regression-based approach, New York, NY: Guilford Press.

Hill, M., \& Hill, A. (2002). Investigação por questionário, Lisboa: Edições Sílabo.

Hobfoll, S. E. (1989). Conservation of resources: a new attempt at conceptualizing stress. American Psychologist, 44(3), 513-524.

Huselid, M. A. (1995). The impact of human resource management practice on turnover, productivity and corporate financial performance. Academy of Management Journal, 38, 635-672. 
EJMS 25,1

Jimenez, D. J., \& Valle, R. S. (2013). Studying the effect of HRM practices on the knowledge management process. Personnel Review, 42(1), 28-49. Retrieved from: http://dx.doi.org/10.1108/ 00483481311285219

Jöreskog, K. G., \& Sörbom, D. (1993). LISREL8: Structural equation modelling with the SIMPLIS command language, Chicago, IL: Scientific Software International.

Kalleberg, A. L., \& Rognes, J. (2000). Employment relations in Norway: some dimensions and correlates. Journal of Organizational Behavior, 21(3), 315-335.

Kim, S. (2005). Factors affecting state government information technology employee turnover intentions. American Review of Public Administration, 35(2), 137-156.

Kim, N. (2014). Employee turnover intention among newcomers in travel industry. International Journal of Tourism Research, 16(1), 56-64, doi: 10.1002/jtr.1898.

Krishnapriya, V., \& Baral, R. (2014). Supply chain integration - A competency based perspective. International Journal of Managing Value and Supply Chains, 5(3), 45-60.

Lee, C. H., \& Bruvold, N. T. (2003). Creating value for employees: investment in employee development. The International Journal of Human Resource Management, 14(6), 981-1000.

Lynch, R. L., \& Cross, K. F. (1991). Measure up - the essential guide to measuring business performance, Mandarin: London.

Maertz, C. P., Jr, Griffeth, R. W., Campbell, N. S., \& Allen, D. G. (2007). The effects of perceived organizational support and perceived supervisor support on employee turnover. Journal of Organizational Behavior, 28(8), 1059-1075.

Markowitsch, J. Kollinger, I. Warmerdam, J. Moerel, H. Konrad, J. Burell, C., \& Guile, D. (2001). Competence and human resource development in multinational companies in three european union member states: a comparative analysis between Austria, The Netherlands and the U.K. Thessaloniki: CEDEFOP.

Marôco, J. (2014). Análise de equações estruturais. Fundamentos teóricos, SoftWare e aplicações, 2nd ed., ReportNumber, Lda: Pero Pinheiro.

Meyer, J. P. (2014). Organizational commitment. In. Guest, D.E and Needle, D. (Eds), Human Resource Management, (Vol. 5 of the Wiley Encyclopedia of Management (199-201), 3rd ed., Chichester, UK: Wiley.

Meyer, J. P., \& Allen, N. J. (1991). A three-component conceptualization of organizational commitment. Human Resource Management Review, 1(1), 61-89.

Meyer, J. P., \& Allen, N. J. (1997). Commitment in the workplace: Theory, research, and application, Thousand Oaks, CA: Sage Publications.

Meyer, J. P., \& Herscovitch, L. (2001). Commitment in the workplace: toward a general model. Human Resource Management Review, 11(3), 299-326.

Meyer, J. P., \& Smith, C. A. (2000). HRM practices and organizational commitment: Test of a mediation model. Canadian Journal of Administrative Sciences/Revue Canadienne Des Sciences de L'administration, 17(4), 319-331.

Meyer, J. P., Allen, N. J., \& Smith, C. A. (1993). Commitment to organizations and occupations: Extension and test of a three-component conceptualization. Journal of Applied Psychology, 78(4), 538-551.

Meyer, J. P., Allen, N. J., \& Topolnytsky, L. (1998). Commitment in a changing world of work. Canadian Psychology/Psychologie Canadienne, 39(1-2), 83-93.

Meyer, J. P., Becker, T. E., \& Van den Berghe, C. (2004). Employee commitment and motivation: a conceptual analysis and integrative model. Journal of Applied Psychology, 89(6), 991-1007.

Meyer, J. P., Stanley, D. J., Herscovitch, L., \& Topolnytsky, L. (2002). Affective, continuance, and normative commitment to the organization: a Meta-analysis of antecedents, correlates, and consequences. Journal of Vocational Behavior, 61(1), 20-52. 
Mincer, J., \& Higuchi, Y. (1988). Wage structures and labour turnover in the United States and Japan. Journal of the Japanese and International Economies, 2(2), 97-133.

Mowday, R. T., Porter, L. W., R. M., \& Steers, R. M. (1982). Employee-organization linkages: the psychology of commitment, absenteeism, and turnover, New York, NY: Academic Press.

Nelissen, J., Forrier, A., \& Verbruggen, M. (2016). Employee development and voluntary Turnover: testing the employability paradox. Human Resource Management Journal, 27(1), 152-168.

Competences development and turnover intentions

Ng, T. W. H. (2015). The incremental validity of organizational commitment, organizational trust, and organizational identification. Journal of Vocational Behavior, 88, 154-163.

Ostroff, C., \& Clark, M. A. (2001). Maintaining an internal market: Antecedents of willingness to change jobs. Journal of Vocational Behavior, 59(3), 425-453.

Pinto, A. M., \& Chambel, M. J. (2008). Abordagens teóricas no estudo do burnout e do engagement. nA. M. Pinto, \& M. J. Chambel, (Eds), Burnout e engagement em contexto organizacional: Estudos com amostras portuguesas, pp. 53-84. Lisboa: Livros Horizonte. I

Podsakoff, P. M., MacKenzie, S. B., Lee, J. Y., \& Podsakoff, N. P. (2003). Common method biases in behavioral research: a critical review of the literature and recommended remedies. Journal of Applied Psychology, 88(5), 879-903.

Rahman, W., \& Nas, Z. (2013). Employee development and turnover intention: theory validation. European Journal of Training and Development, 37(6), 564-579.

Reich, B. S. (2008). The configuration of employee retention practices in multinational corporations foreign subsidiaries. International Business Review, 17, 676-687.

Roehling, M., Cavanaugh, M., Moynihan, L., \& Boswell, W. (2000). The nature of the new employment relationship: a content analysis of the practitioner and academic literatures. Human Resource Management, 39(4), 305-320.

Sánchez-Manjavacas, A., Saorín-Iborra, M., \& Willoughby, M. (2014). Internal employability as a strategy for key employee retention. Innovar, 24(53), 7-22.

Schmidt, J. A., Willness, C. R., Jones, D. A., \& Bourdage, J. S. (2016). Human resource management practices and voluntary turnover: a study of internal workforce and external labor market contingencies. The International Journal of Human Resource Management, 29(3), 571-594, doi: 10.1080/09585192.2016.1165275.

Schneider, B., Brief, A. P., \& Guzzo, R. A. (1996). Creating a climate and culture for sustainable organizational change. Organizational Dynamics, 24(4), 6-19.

Schultz, T. W. (1961). Investment in human capital. The American Economic Review, 51(1), 1-17.

Shore, L. M., Tetrick, L. E., Lynch, P., \& Barksdale, K. (2006). Social and economic exchange: Construct development and validation. Journal of Applied Social Psychology, 36(4), 837-867.

Slavich, B., Cappetta, R., \& Giangreco, A. (2014). Exploring the link between human resource practices and turnover in multi-brand companies: the role of brand units' images. European Management Journal, 32(2), 177-189, doi: 10.1016/j.emj.2013.06.001.

Tanure, B., Evans, P., \& Pucik, V. (2007). Virtudes e pecados capitais: a gestão de pessoas no brasil, Rio de Janeiro: Elsevier.

Trochim, W. (2000). The research methods knowledge base, 2nd ed., Cincinnati, OH: Atomic Dog Publising.

Usmani, S. (2016). Perceived internal employability and leader member exchange as a way to reduce intention to quit via commitment. Humanities and Social Sciences Review, 5(2), 17-32.

Wang, X. H., Zhang, L., \& Xiongfei, C. (2011). Constructing a decision support system for management of employee turnover risk [eletronic version]. Information Technology and Management, 12(2), 187-196. 
EJMS

25,1

Wasti, S. A. (2003). Organizational commitment, turnover intentions and the influence of cultural values. Journal of Occupational and Organizational Psychology, 76(3), 303-321.

Wayne, S. J., Shore, L. M., \& Liden, R. C. (1997). Perceived organizational support and leader-member exchange: a social exchange perspective. Academy of Management Journal, 40, 82-111.

Wright, P., Dunford, B., \& Snell, S. (2001). Human resources and the resource based view of the firm. Journal of Management, 27(6), 701-721.

Yang, J. T., Wan, C. S., \& Fu, Y. J. (2012). Qualitative examination of employee turnover and retention strategies in international tourist hotels in Taiwan. International Journal of Hospitality Management, 31(3), 837-848.

\section{Corresponding author}

Ana Moreira can be contacted at: amoreira@ispa.pt

For instructions on how to order reprints of this article, please visit our website: www.emeraldgrouppublishing.com/licensing/reprints.htm Or contact us for further details: permissions@emeraldinsight.com 